\title{
Modelling Interstate Tourism Demand in Australia: A Cointegration Approach
}

\author{
David Allen, Riaz Shareef and Ghialy Yap* \\ Faculty of Business and Law, Edith Cowan University, Perth, Australia \\ *Email: choyy@student.ecu.edu.au
}

Keywords: Interstate tourism, Australia, cointegration, economic determinants

\section{EXTENDED ABSTRACT}

The interstate tourism industry has received considerable attention from tourism stakeholders. Based on recent statistics, the total expenditure by interstate visitors for the year ended 31 March 2007 was AUD17.5 billion, compared to AUD16.7 billion for the expenditure by an intrastate visitor (Tourism Research Australia, 2007). Furthermore, the average expenditure for interstate visitor was AUD710 whereas AUD324 for intrastate visitor. The figures above demonstrate that interstate tourism is important for domestic tourism business in Australia. Despite this fact, however, an empirical analysis of interstate tourism demand has not been carried out in the tourism literature. The motivation of this paper is to investigate the shortand long-run causal relationships between economic factors and interstate tourism demand in Australia.

The paper hypothesizes that household income, the price of tourist accommodation, prices of recreation and restaurants, fuel prices, domestic airfares and prices of overseas holidays can affect interstate tourism demand. A cointegration approach is employed to carry out the causal analysis, using the quarterly data on the number of nights spend away from home by interstate visitors between 1998 and 2006.

This study finds that the short-run coefficients for income, accommodation price, prices of recreation and restaurants and domestic airfares are statistically significant, implying that any changes in income and prices in tourism goods and services affect the demand for interstate travel in the shortrun. However, this study also discovers that changes in prices of overseas holidays do not have significant impacts on the demand in the short-run. A possible explanation is that decision to travel overseas requires longer budget planning than interstate travel and hence, changes in the prices of overseas holidays in the short-run do not influence Australian residents to travel interstate. Furthermore, short-term changes in fuel prices do not affect interstate tourism demand.
There are several distinctive results regarding the long-run relationships between economic variables and interstate tourism demand. First, among the variables, the long-run coefficients of fuel prices, domestic airfares and prices of overseas holidays are consistent with economic theory. The elasticities of fuel prices and domestic airfares are negative, and positive for the elasticities of the prices of overseas holidays. Second, the coefficients of accommodation price are positive, which seems inconsistent with the prior expectations based on economic theory. The positive coefficients imply that interstate visitors are willing to stay more nights even if the price of accommodation rises. Third, changes in income and prices of recreation and restaurants can significantly influence interstate tourism demand in the long-run. The empirical results reveal that an increase in income can lead to a decrease in the demand because there is a tendency for Australian residents to choose overseas holidays when household income increases in the long-run. Furthermore, this study also discovers that a $1 \%$ increase in the prices of recreation and restaurants will lead to $0.84 \%$ increase in interstate tourism demand in the long-run. This indicates that, to a certain extent, an increase in the prices of recreation and restaurants will not lead to a decline in interstate tourism demand. 


\section{INTRODUCTION}

In Australia, domestic tourism has greater impacts on a state's economy than international tourism. Dwyer et al. (2003) measured the economic impacts of an AUD1 million increase in tourist expenditure by domestic and international tourists on the economy of New South Wales. The study revealed that domestic tourists' spending would generate an additional AUD0.71 million in gross state product (GSP) and create 11 jobs for the state, whereas international tourists would increase AUD0.393 million in GSP and create additional 6 jobs. There are also more domestic tourists as 203 million domestic tourists in Australia consumed $75.8 \%$ of Australian tourism goods and services while five million international tourists consumed 24.2\% (Australian Bureau Statistics, 2005-06).

Interstate travellers in Australia are relatively higher spenders than intrastate visitors. On average, the duration of travel and expenditure per interstate visitor was 5.4 nights and AUD710, respectively, which is approximately twice the amount of travel duration and expenditure per intrastate visitor. Moreover, most of the interstate visitors were holiday-makers and visiting friends and relatives, which both accounted for 19 million people or $76 \%$ of the overall number of interstate visitors for the year ended 31 March 2007.

According to recent statistics, the total expenditure by interstate visitors for the year ended 31 March 2007 was AUD17.5 billion, compared to AUD16.7 billion for the expenditure by intrastate visitors (Tourism Research Australia, 2007a). Furthermore, Figure 1 demonstrates that expenditure by interstate visitors was the main source of revenue for tourism industries in Queensland, South Australia, Tasmania, Northern Territory and Australian Capital Territory. For Victoria, the expenditure by interstate visitors was slightly higher than the expenditure by intrastate and international visitors. However, West and Gamage (2001) employed a non-linear inputoutput model to study the economic impacts of tourism on the Victorian economy and they discovered that interstate tourism contributes the greatest amount to gross state product and employment in the Victorian economy in Australia, followed by international visitors. In conclusion, interstate tourism is important in terms of generating tourism revenue for six Australia States. Therefore, it is imperative to sustain a growth in interstate tourism demand in Australia.

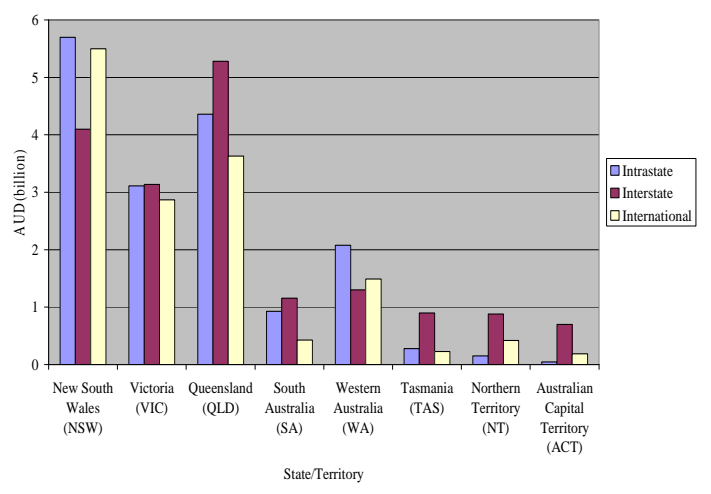

Figure 1. Visitor expenditure in each

States/Territory for the year ended 31 March 2007 (Source: Based on Tourism Research Australia, 2007a and 2007b)

In the tourism literature, the demand analysis of interstate tourism has not been assessed thoroughly. The intention of this paper is to investigate the effects of economic factors on interstate tourism demand. The objectives of the paper are two-fold. First, this paper will construct a demand model for interstate tourism. Second, the model will be employed to examine the causal relationships between the economic factors and interstate tourism demand in Australia in the shortand long-run. The contribution of the paper is to generate an interstate tourism demand model for the purpose of forecasting and planning marketing strategies for interstate tourism.

\section{A MODEL FOR INTERSTATE TOURISM DEMAND}

The study of economic determinants of tourism demand have been well-documented in the literature on modelling tourism demand. Lim (1999) concluded that tourists' income, prices of tourism goods and services and transportation costs are the most important determinants that influence international tourism demand.

In the context of Australian domestic tourism demand, the literature reveals that domestic tourists' income and prices of tourism goods and services are the main economic determinants that influence Australians to travel domestically (Athanasopoulos and Hyndman, 2006; Divisekera, 2007; Hamal, 1996). Furthermore, domestic tourists make choices between domestic destinations, by comparing the costs between travelling to intrastate and interstate destinations (Huybers, 2003).

Seddighi and Shearing (1997) argue that the elements of tourism prices are the costs of travel to destination and the cost of living at the destination. 
Hence, this study proposes domestic airfares as the cost of travel, as well as prices of tourist accommodation, recreation and restaurants as the costs of living.

Despite domestic airfares, transportation costs also strongly relate to the costs of fuel. Tourism Forecasting Committee (2006) incorporated the price of fuel in modelling Australian domestic tourism demand and assumed that rising costs of fuel will reduce the number of domestic night stays. Hultkrantz (1995) found that petrol taxes in Sweden had increased since 1990, thereby increasing transportation costs in Sweden and reducing the number of domestic trips by Swedish households. Given this fact, price of fuel should be included in a domestic tourism demand model as a proxy for transportation costs.

Prices of substitute products are important economic determinants in tourism demand analysis. In the tourism literature, it is wellacknowledged that domestic tourism is a substitute product for international tourism demand (Lim, 1997 and Patsouratis et al., 2005). Conversely, prices of overseas holidays can affect domestic tourism demand. Hamal (1996) discovered that the correlation between domestic holiday nights in Australia and prices of overseas holidays is positive, implying that increases in the costs of overseas travel will lead to a growth in the demand for domestic holidays.

Based on the literature of tourism demand above, an interstate tourism demand model can be written as follows:

$$
D I T=f(Y, A C C, R R, F, D A, O C)
$$

where $D I T=$ interstate tourism demand, $Y=$ income, $A C C=$ price of tourist accommodation, $R R=$ prices of recreation and restaurants, $F=$ price of fuel, $D A=$ domestic airfares and $O C=$ prices of overseas holidays.

\section{DATA}

Data on interstate tourism demand can be obtained from Travel by Australians, which is produced quarterly by Tourism Research Australia. In this paper, data on interstate visitor nights will be employed. As highlighted by Faulkner (1988), statistics based on visitor nights are significant from an economic viewpoint because they reflect the utilisation of tourism facilities and related tourism expenditure.

For economic variables, gross domestic product (GDP) per capita is employed as a proxy for income variable. For prices of tourism goods and services in Australia, data on average price of accommodation per night and household expenditure on recreation, restaurant and cafes are used. In addition, the consumer price index (CPI) of automotive fuel and domestic economy airfares are used as a proxy variable for domestic transportation costs. This paper also employs data on CPI of overseas holidays, travel and accommodation to represent the price of substituting interstate travel.

All the abovementioned economics data are available on a quarterly basis from quarter 3 of 1998 to quarter 4 of 2006 and can be obtained from the websites of the Australian Bureau of Statistics (ABS) and Department of Transport and Regional Services (DOTARS).

\section{COINTEGRATION ANALYSIS AND ERROR-CORRECTION MODEL}

The interstate tourism demand model, Equation (1), is specified as a log-linear model because it is easy to interpret the estimated coefficients in terms of elasticities (Lim, 1997). In fact, log-linear models have been widely used in the literature on tourism demand (Lim and McAleer, 2001; Seddighi and Shearing, 1997).

To investigate the long-term relationship between economic variables and domestic interstate tourism demand, cointegration and error-correction models will be employed. These models are useful because they provide long-run and short-run estimations for the purpose of long-term tourism planning and short-term business forecasting (Song and Witt, 2000).

The first step in testing cointegration is to ensure that all economic variables have the same order of integration. The order of integration can be tested using an augmented Dickey-Fuller (ADF) test, which is written as follows:

$\Delta z_{t}=\alpha+\beta z_{t-1}+\sum_{i=1}^{p-1} \gamma_{i} \Delta z_{t-i}+\lambda T+e_{t}$

where $z=$ time series of a variable, $T=$ time trend, $p=$ number of lag value and $e=$ error term. The hypotheses of the $\mathrm{ADF}$ test are specified as follows:
Ho: $\beta=0$
$\mathrm{H}_{1}: \beta<0$

If the null hypothesis is not rejected, this implies that the data is non-stationary. Conversely, the rejection of the null hypothesis indicates that the data is stationary or I(0). Song and Witt (2000) highlighted that it is important to select the 
appropriate lag length for all time series data because the ADF test tends to over-reject the null hypothesis when using too few lags or to reduce degrees of freedom when there are too many lags. This paper employs the Akaike information criterion (AIC) and Schwarz Bayesian criterion (SBC) as the criteria for selecting the lag length of the ADF test.

Nevertheless, Phillips and Perron (1990) argued that ADF test is rather restrictive because the test assumes no autocorrelation and heteroscedesticity in the estimated residuals. Hence, the PhillipsPerron (PP) test will be employed because the test relaxes the abovementioned assumptions.

Johansen's (1995) cointegration procedure will be employed in this study. To illustrate the procedure,

let $Z_{t}=\left(\begin{array}{l}D I T_{t} \\ Y_{t} \\ A C C_{t} \\ R R_{t} \\ F_{t} \\ D A_{t} \\ O C_{t}\end{array}\right), \quad$ then, the vector

autoregressive (VAR) can be written as:

$Z_{t}=\mathrm{B}_{1} Z_{t-1}+\mathrm{B}_{2} Z_{t-2}+\ldots+\mathrm{B}_{P} Z_{t-P}+U_{t}$

where $p=$ number of lags, $\mathrm{B}_{i}=$ an $\left(\begin{array}{lll}m & \mathrm{x} & m\end{array}\right)$ matrix of parameters, and $U_{t}=$ error term.

To obtain the error-correction mechanism, equation (2) is transformed as follows:

$\Delta Z_{t}=\sum_{i=1}^{P-1} \Phi_{i} \Delta Z_{t-i}+\Phi Z_{t-P}+U_{t}$

where $\Phi_{i}=-\left(I-\mathrm{B}_{1}-\mathrm{B}_{2}-\ldots-\mathrm{B}_{i}\right)$, and $\Phi=-\left(I-\mathrm{B}_{1}-\mathrm{B}_{2}-\ldots-\mathrm{B}_{p}\right) . \Phi_{i}$ and $\Phi$ are short-run and long-run adjustments to the changes in $Z_{t}$, respectively. Equation 3 is named as vector error-correction model (VECM). The equilibrium relationship can be expressed as:

$\Phi=\alpha \beta^{\prime}$

where $\alpha$ is the speed of adjustment to disequilibrium, and $\beta^{\prime}$ is a set of cointegrating vectors. The existence of cointegration relationships can be determined by the rank of $\Phi$,

$r \leq(m-1)$. To choose $r$, maximal eigenvalue and trace tests will be employed.

In the long-run, the cointegrated parameters are expressed as follows:

$D I T=\lambda_{1}+\lambda_{2} Y+\lambda_{3} A C C+\lambda_{4} R R+\lambda_{5} F+\lambda_{6} D A+\lambda_{7} O C$

The signs of the long-run cointegration parameters are expected as follows: $\lambda_{2}>0, \lambda_{3}<0, \lambda_{4}<0$, $\lambda_{5}<0, \lambda_{6}<0$ and $\lambda_{7}>0$.

\section{EMPIRICAL RESULTS}

Prior to conducting the cointegration analysis, it is important to determine the order of integration of all economic variables. ADF test statistics in Table 1 and 2 show that the logarithms and logdifference of DIT, Y and RR are I(0), but I (1) for ACC, F, DA and OC. Based on the ADF test results, it concludes that the first difference of all variables do not have the same order of integration. However, the PP test statistics in Table 1 and 2 reveal a different perspective. The logarithms of ACC, F, DA and OC are I(1) and the rest of the variables are $\mathrm{I}(0)$. Eventually, all variables become $\mathrm{I}(0)$ after taking the first difference. In other words, the results of PP test imply that the first difference of all variables have the same order of integration.

In the literature of international tourism demand, Chan et al. (2005) and Shareef and McAleer (2007) preferred the PP test over the ADF test when analysing time series data. They assert that PP test has higher power in finite samples than ADF test. As PP test is more robust than ADF test, this study prefers the results of PP test which concludes that same order of integration exists in all economic variables.

Table 1. Unit root test statistics for economic variables in logarithms

\begin{tabular}{lccc}
\hline Variable & ADF test & $\begin{array}{c}\text { Lag } \\
\text { length of } \\
\text { ADF }\end{array}$ & PP test \\
\hline DIT & -3.5176 & 1 & -10.4084 \\
Y & -3.6361 & 0 & -3.7227 \\
ACC & $-2.1791^{*}$ & 4 & $-2.8031^{*}$ \\
RR & -5.8312 & 0 & -9.1065 \\
F & $-2.8248^{*}$ & 4 & $-2.3213^{*}$ \\
DA & $-2.4115^{*}$ & 4 & $-2.2360^{*}$ \\
OC & $-1.3813^{*}$ & 3 & $-1.7291^{*}$ \\
\hline Note: Critical values at 5\% for ADF and PP tests are \\
-3.5731 and -3.5514, respectively. * denotes null \\
hypothesis is not rejected.
\end{tabular}


Table 2. Unit root test statistics for economic variables in log-difference

\begin{tabular}{lccc}
\hline Variable & ADF test & $\begin{array}{c}\text { Lag } \\
\text { length of } \\
\text { ADF }\end{array}$ & PP test \\
\hline DIT & -5.1900 & 1 & -33.2893 \\
Y & -5.4870 & 0 & -6.0926 \\
ACC & $-2.7954^{*}$ & 4 & -7.3072 \\
RR & -6.9141 & 0 & -14.6024 \\
F & $-2.4475^{*}$ & 4 & -4.8503 \\
DA & $-2.5635^{*}$ & 4 & -4.8403 \\
OC & $-1.8004^{*}$ & 4 & -5.4413 \\
\hline
\end{tabular}

Note: Critical values at $5 \%$ for ADF and PP tests are -3.5796 and -3.5562 , respectively. * denotes null hypothesis is not rejected.

Given the above results, Johansen's cointegration analysis can be carried out using Microfit 4.0. The initial step is to specify a lag length for the VAR model. Based on test statistics for selecting the order of VAR model (not reported here), this study chooses VAR(2) model.

To determine $r$ or the number of cointegrating vectors, maximal eigenvalue and trace tests are carried out (Tables 3 and 4). Based on the likehood ratio statistics of both tests, there is no single conclusion found from the tests. The maximal eigenvalue test suggests that the number of cointegrating vectors is three while the trace test recommends five. This paper chooses $r=3$ because, according to Seddighi and Shearing (1997), the maximal eigenvalue test has greater power than the trace test.

For the error-correction terms, the first and third cointegrating vectors are statistically significant (Table 5). This indicates that there are two sets of long-run coefficients for interstate tourism demand.

Table 3. Maximal eigenvalue test for cointegrating vectors

\begin{tabular}{lllll}
\hline $\begin{array}{r}\text { Null } \\
\text { hypothesis }\end{array}$ & $\begin{array}{l}\text { Alternative } \\
\text { hypothesis }\end{array}$ & $\begin{array}{l}\text { Likelihood } \\
\text { ratio (LR) } \\
\text { statistics }\end{array}$ & $\begin{array}{l}5 \% \\
\text { critical } \\
\text { value }\end{array}$ & $\begin{array}{l}10 \% \\
\text { critical } \\
\text { value }\end{array}$ \\
\hline$r=0$ & $r=1$ & 86.5371 & 46.47 & 43.44 \\
$r<=1$ & $r=2$ & 59.6172 & 40.53 & 37.65 \\
$r<=2$ & $r=3$ & 38.9532 & 34.40 & 31.73 \\
$r<=3$ & $r=4$ & 23.3572 & 28.27 & 25.80 \\
$r<=4$ & $r=5$ & 15.7629 & 22.04 & 19.86 \\
$r<=5$ & $r=6$ & 11.5702 & 15.87 & 13.81 \\
$r<=6$ & $r=7$ & 8.4509 & 9.16 & 7.53 \\
& & & & \\
\hline
\end{tabular}

Note: The hypotheses above are to determine the number of cointegrating vectors, $r$.
Table 4. Trace tests for cointegrating vectors

\begin{tabular}{|c|c|c|c|c|}
\hline $\begin{array}{l}\text { Null } \\
\text { hypothesis }\end{array}$ & $\begin{array}{l}\text { Alternative } \\
\text { hypothesis }\end{array}$ & $\begin{array}{l}\text { Likelihood } \\
\text { ratio (LR) } \\
\text { statistics }\end{array}$ & $\begin{array}{l}5 \% \\
\text { critical } \\
\text { value }\end{array}$ & $\begin{array}{l}10 \% \\
\text { critical } \\
\text { value }\end{array}$ \\
\hline$r=0$ & $r>=1$ & 244.2486 & 132.45 & 127.24 \\
\hline$r<=1$ & $r>=2$ & 157.7115 & 102.56 & 97.87 \\
\hline$r<=2$ & $r>=3$ & 98.0943 & 75.98 & 71.81 \\
\hline$r<=3$ & $r>=4$ & 59.1412 & 53.48 & 49.95 \\
\hline $\begin{array}{l}r<=4 \\
r<=5\end{array}$ & $\begin{array}{l}r>=5 \\
r>=6\end{array}$ & $\begin{array}{l}35.7839 \\
20.0211\end{array}$ & $\begin{array}{l}34.87 \\
20.18\end{array}$ & $\begin{array}{l}31.93 \\
17.88\end{array}$ \\
\hline$r<=6$ & $r>=7$ & 8.4509 & 9.16 & 7.53 \\
\hline
\end{tabular}

Note: The hypotheses above are to determine the number of cointegrating vectors, $r$.

Table 5. Error-correction model

\begin{tabular}{|c|c|c|c|}
\hline Variable & Coefficient & t-ratio & p-value \\
\hline$\Delta \mathrm{DIT}(-1)$ & -0.1458 & -1.0871 & 0.289 \\
\hline$\Delta \mathrm{Y}(-1)$ & -3.2161 & -3.1894 & 0.004 \\
\hline$\triangle \mathrm{ACC}(-1)$ & -1.6222 & -3.6694 & 0.001 \\
\hline$\Delta \mathrm{RR}(-1)$ & 1.0309 & 3.2663 & 0.004 \\
\hline$\Delta \mathrm{F}(-1)$ & 0.0632 & 0.2753 & 0.786 \\
\hline$\Delta \mathrm{DA}(-1)$ & 3.1397 & 3.7814 & 0.001 \\
\hline$\Delta \mathrm{OC}(-1)$ & -0.0767 & -0.2051 & 0.839 \\
\hline$Z_{1, t-1}$ & 0.2104 & 3.9976 & 0.001 \\
\hline$Z_{2, t-1}$ & 0.0772 & 1.4671 & 0.157 \\
\hline$Z_{3, t-1}$ & 0.2299 & 4.3684 & 0.000 \\
\hline Adjusted $\mathrm{R}^{2}$ & & 0.9329 & \\
\hline Diagnostic tests: & & $\begin{array}{r}\text { Chi- } \\
\text { squared }\end{array}$ & p-value \\
\hline Serial correlation & & 7.0205 & 0.135 \\
\hline RESET & & 0.0049 & 0.944 \\
\hline $\begin{array}{l}\text { Normality } \\
\text { Heteroscedesticity }\end{array}$ & & 0.1822 & 0.913 \\
\hline Heteroscedesticity & & 0.8392 & 0.360 \\
\hline
\end{tabular}

The diagnostic tests reveal that the error-correction model is correctly specified. Based on the test results in Table 5, the residual of the model does not have problems of misspecification, serial correlation and heteroscedasticity. The model also does not reject the null hypothesis of normality.

The signs of long-run coefficients for variables $\mathrm{F}$, DA and OC in Table 6 are consistent with the economic theory. In the long-run, a $1 \%$ increases in fuel price and domestic airfares will lead to a decline in interstate tourism demand up to $3.65 \%$ and $22 \%$, respectively. On the other hand, a $1 \%$ rises in the price of overseas holidays, the number of interstate night stays will increase up to $7.17 \%$. 
However, the relationship between interstate tourism demand and accommodation price (ACC) does not support economic theory. The figures in Table 6 show that the coefficients of ACC range between +0.93 and +21.08 , indicating that a rise in accommodation price increases the number of interstate visitor nights.

Table 6. Long-run coefficients for interstate

\begin{tabular}{lrr}
\multicolumn{3}{c}{ tourism demand } \\
\hline Variable & Cointegrating & Cointegrating \\
& vector 1 & vector 2 \\
\hline DIT & -0.1910 & -4.9590 \\
& {$[-1.000]$} & {$[-1.000]$} \\
Y & 9.0357 & -3.8091 \\
& {$[47.3128]$} & {$[-0.7681]$} \\
ACC & 4.0252 & 4.6257 \\
& {$[21.0765]$} & {$[0.9328]$} \\
RR & -6.6220 & 4.1764 \\
& {$[-34.6742]$} & {$[0.8422]$} \\
F & -0.6980 & -2.3688 \\
& {$[-3.6548]$} & {$[-0.4777]$} \\
DA & -4.1979 & -1.4977 \\
& {$[-21.9812]$} & {$[-0.3020]$} \\
OC & 1.3696 & 2.3998 \\
& {$[7.1713]$} & {$[0.4839]$} \\
Intercept & -15.4984 & 32.7175 \\
& {$[-81.1525]$} & {$[6.5976]$} \\
\hline Note: Figures
\end{tabular}

Note: Figures in brackets are normalized value.

Table 6 also reveals that the long-run coefficients for income and prices of recreation and restaurants are +47.31 and -34.67 , respectively. This indicates that income and prices of tourism goods and services have significant impacts on the interstate tourism demand in the long-run. However, this study also finds that the long-run income elasticities can be -0.77 . One of the possible explanations is that, even if household income increases in the long-run, Australian residents will likely choose not to travel domestically because it is preferential to use their income for overseas holidays (Athanasopoulos and Hyndman, 2007). In addition, the long-run elasticities of the prices of recreation and restaurants can be +0.84 , implying that, to a certain extent, an increase in the prices of recreation and restaurants will not reduce the number of night stays by interstate visitors.

\section{CONCLUDING REMARKS}

This paper has carried out error-correction model and Johansen's cointegration analysis to examine the short- and long-run relationships between interstate tourism demand in Australia and its economic determinants.

The study discovered several distinctive results. First, changes in income, price of accommodation, domestic airfares, and prices of recreation and restaurants can influence interstate tourism demand in the short-run.
Second, the signs of long-run coefficients for fuel prices, domestic airfares and price of overseas holidays are consistent with the economic theory. For transportation costs, the results demonstrated that interstate visitors are relatively more sensitive to the changes in domestic airfares than fuel prices.

Third, changes in income and prices of recreation and restaurants can significantly affect the demand for interstate tourism in the long-run. This study also found that an increase in income can lead to a decrease in the demand because Australian residents perhaps may prefer to use their additional income for overseas holidays. Furthermore, to a certain extent, an increase in the price of recreation and restaurants will not lead to a decline in interstate tourism demand.

Fourth, the long-run elasticities of accommodation cost are positive, which signify that a rise in accommodation price will increase the number of night stays by interstate visitors. Further investigation on positive relationship between interstate tourism demand and accommodation price is required because the relationship is not consistent with prior expectations based on economic theory.

Overall, the diagnostic tests certified that there are no serial correlation, misspecification, nonnormality and heteroscedesticity issues in the residual of the error-correction model. In other words, the interstate tourism demand model, which is proposed in this paper, is correctly specified. Given this fact, the model can be employed by tourism stakeholders to plan pricing policies and marketing strategies for promoting interstate tourism.

\section{REFERENCES}

Athanasopoulos, G. and R. J. Hyndman (2007), Tourism Management, doi:10.1016/j.tour man.2007.04.009.

Australian Bureau of Statistics (2005-06), Australian National Accounts: Tourism Satellite Account No. 5249.0, Australian Bureau of Statistics, 50 pp., Canberra.

Chan, F., C. Lim and M. McAleer (2005), Modelling multivariate international tourism demand and volatility, Tourism Management, 26(3), 459-471.

Divisekera, S. (2007), Domestic demand for Australian tourism: Elasticity estimates, CRC for Sustainable Tourism Pty Ltd, 42 pp., Queensland. 
Dwyer, L., P. Forsyth, R. Spurr and T.Vanho (2003), Tourism's contribution to a state economy: A multi-regional general equilibrium analysis, Tourism Economics, 9(4), 431-448.

Faulkner, B. (1988), Tourism demand patterns Australia, International Journal of Hospitality Management, 7(4), 333-341.

Hamal, K. (1996), Modelling domestic holiday tourism demand in Australia: Problems and solutions, Asia Pacific Journal of Tourism Research, 1(2), 35-46.

Hultkrantz, L. (1995), On determinants of Swedish recreational domestic and outbound travel, Tourism Economics, 1(2), 119-145.

Huybers, T. (2003), Domestic tourism destination choices - A choice modelling analysis, International Journal of Tourism Research, 5(6), 445-459.

Johansen, S. (1995), Likelihood-based Inference in Cointegrated Vector Autoregressive Models, Oxford University Press, 267 pp., New York.

Lim, C. (1997), Review of international tourism demand models, Annals of Tourism Research, 24(4), 835-849.

Lim, C. (1999), A meta-analytic review of international tourism demand, Journal of Travel Research, 37(3), 273-284.

Lim, C. and M. McAleer (2001), Cointegration analysis of quarterly tourism demand by Hong Kong and Singapore for Australia, Applied Economics, 33(12), 1599-1619.

Patsouratis, V., Z. Frangouli and G. Anastasopoulos (2005), Competition in tourism among the Mediterranean countries, Applied Economics, 37(16), 1865-1870.

Phillips, P. C. B. and P. Perron (1990), Testing for a unit root in time series regressions, Biometrika, 75(2), 335-346.

Seddighi, H. R. and D. F. Shearing (1997), The demand for tourism in North East England with special reference to Northumbria: An empirical analysis, Tourism Management, 18(8), 499-511.
Shareef, R. and M. McAleer (2007), Modelling the uncertainty in monthly international tourist arrivals to the Maldives, Tourism Management, 28(1), 23-45.

Song, H. and S. F. Witt (2000), Tourism Demand Modelling and Forecasting: Modern Econometric Approach, Elsevier Science Ltd, 178 pp., Oxford.

Tourism Forecasting Committee (2006), Forecast: April 2006, Tourism Research Australia, 72 pp., Canberra.

Tourism Research Australia (2007a), Travel by Australians March quarter 2007, Tourism Research Australia, 40 pp., Canberra.

Tourism Research Australia (2007b), International Visitors in Australia March quarter 2007, Tourism Research Australia, 58 pp., Canberra.

West, G. and A. Gamage (2001), Macro-effects of tourism in Victoria, Australia: A nonlinear input-output approach, Journal of Travel Research, 40(1), 101-109. 